\title{
New room to maneuver? National tax policy under in- creasing financial transparency
}

Leo Ahrens (University of Bamberg - Feldkirchenstr. 21, 96052 Bamberg, Germany)

Fabio Bothner (University of Bamberg - Feldkirchenstr. 21, 96052 Bamberg, Germany)

Lukas Hakelberg (Freie Universität Berlin - Ihnestr. 22, 14195 Berlin, Germany)

Thomas Rixen (Freie Universität Berlin - Ihnestr. 22, 14195 Berlin, Germany)

Correspondence: thomas.rixen@fu-berlin.de

Postprint. Please cite as: Ahrens, Leo/Bothner, Fabio/Hakelberg, Lukas/Rixen, Thomas (2020) New room to maneuver? National tax policy under increasing financial transparency. SocioEconomic Review. https://doi.org/10.1093/ser/mwaa007

Acknowledgements: Funding by the European Commission for the Horizon 2020-Project “Combatting Fiscal Fraud and Empowering Regulators (COFFERS)” is gratefully acknowledged. Previous versions were presented at the ECPR Joint Sessions in Hamburg in August 2018 and at the Oxford University Centre for Business Taxation in December 2018. Vincent Arel-Bundock, Loriana Crasnic, Leonard Geyer, Moran Harari, Niels Johannesen, Simon Linder, Malte Lübker, Jack Mintz and Richard Murphy provided helpful comments and suggestions. Sophia Häuser, Svenja Schrader and Lea Maurer provided research assistance and helped with data collection. We thank all of them!

Funding: This research was funded by the European Commission within the Horizon 2020Project “Combatting Fiscal Fraud and Empowering Regulators (COFFERS)”. 


\title{
New room to maneuver? National tax policy under increasing financial transparency
}

\begin{abstract}
Why have OECD governments raised taxes on dividends at the shareholder level since 2008? Previous research points to the importance of budget deficits and voter demand for compensatory fairness in the aftermath of the financial crisis. We complement this literature by showing that the effect of domestic drivers of tax increases on capital income crucially depends on the level of financial transparency in a country’s investment network. Low financial transparency increases the risk of capital flight in response to a tax hike, whereas high financial transparency reduces this risk. Hence, governments facing fiscal pressure become more likely to raise taxes on capital income when transparency is high. To substantiate our argument, we construct an original indicator of financial transparency in countries' investment networks, which we utilize in a regression analysis of tax reforms by 204 cabinets in 35 OECD countries between 2001 and 2018.
\end{abstract}

Keywords: Capital taxation; globalization; tax evasion; international cooperation; financial transparency; automatic exchange of taxpayer information.

JEL classification: F53, F65, F68, H26, H87 


\section{Introduction}

Policymakers around the world have cut taxes on capital income since the 1980s to attract foreign funds or prevent capital flight (Genschel and Schwarz, 2011). Since the Group of 20 (G20) declared the end of banking secrecy in 2009, however, average tax rates on dividends, interest, capital gains and top incomes in member states of the Organisation for Economic Cooperation and Development (OECD) have increased again (Harding and Marten, 2018; Limberg, 2019). In fact, previous research shows that the G20's financial transparency campaign, which culminated in the automatic exchange of information (AEoI) on accounts held by non-residents, has provided national governments with additional leeway in their tax policy decisions, leading on average to higher taxes on dividends at the shareholder level (Hakelberg and Rixen, 2017). The trend is broad, but it is not uniform. Belgium, for instance, raised the tax rate on dividend payments from 15\% in 2008 to $30 \%$ in 2018, Hungary lowered it from 35\% to $15 \%$ and Sweden kept it constant at 30\%. Why have some governments increased while others cut taxes on dividend payments? What role does the increase in financial transparency play in countries' tax policy decisions and how important is it relative to domestic factors like fairness concerns, party ideology, or budget deficits?

We argue that increased financial transparency is an enabling condition for higher tax rates on portfolio capital because it increases the risk of detection for households with undeclared bank accounts in secretive tax havens. Through the concomitant reduction in the risk of capital flight - the main justification for competitive tax cuts on portfolio capital - transparency provides national governments with new room to maneuver, which they may or may not use for tax increases depending on domestic driving factors. Recent work suggests, for instance, that tax increases since the financial crisis result from exacerbated budget constraints (Lierse and Seelkopf, 2016) and voter demand for compensatory fairness (Limberg, 2019). Earlier contributions expect left governments to impose a higher tax burden on capital income than conservative or liberal governments (Ganghof, 2006). We hypothesize that these factors interact with 
the level of transparency because actually achieving shifts of the tax burden towards capital and increased tax revenue should depend on the risk of detection associated with tax evasion. At the same time, financial transparency should not produce tax increases on its own, since bi- and multilateral treaties establishing it do not provide for minimum tax rates or any other form of tax rate coordination.

To test our argument, we first operationalize a novel measure of financial transparency in countries' respective investment networks. The investment network transparency score (INTS) reveals a strong upward trend in transparency, reflecting the gradual replacement of banking secrecy with increasingly effective methods of information exchange. But this trend is not uniform. Instead, there remains considerable spatial and temporal variation across countries' investment networks. In a second step, we utilize the INTS in a regression analysis of governments' tax rate reforms. Our sample contains data from 204 cabinets in all 35 OECD countries from the years 2001 to 2018 and the dependent variable is cabinet-specific changes in the net tax rates imposed on dividends at the shareholder level. In line with our expectations, we find that only jurisdictions with budget deficits have increased tax rates in reaction to increasing financial transparency in their investment networks. Biases against labor relative to capital income in national tax systems exert upward pressure on dividend tax rates irrespective of the level of financial transparency. In contrast, left-leaning governments do not raise taxes more than right-leaning governments, neither under low nor under high transparency.

The article makes four contributions to the literature on comparative and international political economy. First, we provide future researchers with the INTS, an original indicator of financial transparency that is - unlike other established indicators - comparable across time and therefore useable in time-series cross-section (TSCS) and similar analyses (cf. Cobham et al., 2015). Second, our study speaks to an emerging literature investigating the causes and dynamics of post-crisis tax policy. This literature has so far identified rising sovereign bond yields and voter demand for compensatory fairness as the main determinants of tax increases since 2008 
(Lierse and Seelkopf, 2016; Limberg, 2018). Third, our study relates to work that assesses the effectiveness of various types of international tax cooperation, including information exchange upon request or on an automatic basis (Ahrens and Bothner, 2019; Johannesen and Zucman, 2014; Hakelberg and Schaub, 2018; Rixen and Schwarz, 2012). Fourth, our results shed new light on the big debate of the 1990s and early 2000s concerning the role of globalization versus domestic factors in national tax policy choices (Ganghof, 2006; Garrett and Mitchell, 2001; Genschel, 2002; Swank and Steinmo, 2002). Whereas recent contributions suggest that domestic politics and functional pressures have neutralized the negative impact of tax competition on income tax rates, we show that international cooperation reducing the risk of capital flight had to first provide governments with leeway to address budget deficits by raising tax rates on dividends.

The article is structured as follows: In section 2, we situate our argument in the theoretical debate on the politics of income taxation and derive two hypotheses. We then discuss the evolution of financial transparency and explain our approach towards measuring it in section 3. Section 4 is devoted to the explanation of our method and data, and section 5 to the presentation and discussion of our empirical results. We discuss the broader implications of our study and outline opportunities for further research in section 6 .

\section{Financial Transparency and the Politics of Income Taxation}

Figure 1 plots the development of net tax rates on dividends levied by OECD countries at the shareholder level. Out of 35 member states, 19 have increased their corresponding rates between 2008 and 2018, whereas only four have reduced them over the same time period. Together, these reforms raised the average tax rate in the OECD by more than four percentage points, a striking break with the long-term downward trend observed since the 1980s. Recent tax reforms in OECD countries thus seem to run counter to the expectations of classic theories of tax competition. Financial wealth, which is at the origin of dividend payments, is a very 
mobile tax base. As previous research demonstrates, its owners are highly sensitive to crosscountry differences in tax rates. Therefore, governments should try to keep their tax rates lower than those in other countries to protect their tax bases from capital flight. The result is a race to the bottom that, while not necessarily leading to zero tax rates everywhere, shifts the overall tax burden from capital to less mobile tax bases like labor and consumption, thereby increasing the regressivity of national tax systems (Genschel and Schwarz, 2011, pp. 340-341). However, it seems as if many OECD governments have taken a time-out from this race since 2008. How can we account for their exit from the competition?

[Figure 1: Net personal taxes on dividends in OECD countries]

Recent studies explain a similar upward trend in top marginal income tax rates either with voter demand for compensatory fairness or budget deficits, both induced by the financial crisis of 2008. According to Limberg (2019), the notion that wealthy capital owners, who had benefitted from deregulated financial markets before the crisis, should also shoulder a commensurate share of its cost motivated policymakers in particularly affected countries to raise taxes on the highest income brackets. In contrast, Lierse and Seelkopf (2016) hypothesize that rising sovereign bond yields forced many OECD governments to replace deficit spending with tax increases after 2008. Whereas they find a strong effect of bond yields on the level of the value-added-tax, however, the effect on income taxes does not reach conventional levels of statistical significance in most of their model specifications. Still, both studies lend support to the much older claim that domestic politics in the guise of voters' fairness concerns or functional pressures like budget deficits may cancel out the negative impact of tax competition on tax rates imposed on mobile tax bases (Plümper et al., 2009; Swank and Steinmo, 2002). ${ }^{1}$

In fact, authors skeptical towards theories of tax competition have identified several additional factors that may prevent ever lower capital income taxes. As to domestic politics, 
Basinger and Hallerberg (2004) show that left governments are more likely to maintain or even raise taxes on capital than conservative governments, including when capital mobility is high. Shifting the overall tax burden towards labor and consumption came with higher constituency costs for left governments representing the lower half of the income distribution than for conservative governments, which were more likely to represent capital owners. As to functional pressures, Ganghof (2006) argues that governments often have a hard time switching from a synthetic income tax system, which treats all types of income the same, to a dual income tax system, which charges low rates on mobile capital income and high rates on immobile income from labor. The obvious discrimination of labor income raised political opposition and invited owner-managers to avoid taxes by paying themselves dividends instead of wages. Therefore, some governments maintained high taxes on capital income despite the associated risk of capital flight.

Building on these insights, we theorize that domestic politics and functional pressures are the driving factors behind tax increases on capital income. They motivate governments to propose corresponding tax reforms. But analyses of rising income tax rates since the financial crisis have so far ignored a crucial enabling factor at the international level that determines whether governments can actually implement higher rates. Since the G20 put the end of banking secrecy on their agenda in 2009, OECD governments have achieved remarkable progress in expanding the exchange of information on bank accounts held by non-residents. By making it much harder for the broad mass of capital owners to hide their financial wealth in offshore accounts, rising financial transparency achieved through increasingly effective forms of information exchange reduced the risk of capital flight usually associated with tax hikes on capital income. This is what the recently observed reduction in the value of foreign deposits in tax havens relative to non-havens suggests (Ahrens and Bothner, 2019; Hakelberg and Schaub, 2018).

Previous studies of post-crisis tax reforms implicitly defend the view that domestic politics and functional pressures constrain governments more than global tax competition. In contrast, 
we argue that international cooperation liberated national governments from the structural constraint of tax competition, thereby enabling them to adjust the taxation of capital income to competing political and functional demands. Before the push towards financial transparency, policymakers had reason to believe that a tax hike on capital income would produce tax evasion instead of tax revenue. Despite his preference for progressive taxation, former German finance minister Peer Steinbrück concluded, for instance, that it "[was] better to have 25\% of X than 42\% of nothing” and introduced a tax rebate for capital income in 2006 (Handelsblatt, 2006). After more than a hundred jurisdictions had adopted the OECD’s common reporting standard (CRS) in 2014, thereby committing to AEoI on all forms of capital income, however, Pascal Saint-Amans, the organization's head of tax, defended a new view. He argued that "for the past 30 years we've been saying 'don't try to tax capital more because you'll lose it, you'll lose investment.' Well this argument is dead, so it's worth revisiting the whole story” (Creighton, 2016).

We want to empirically test whether OECD governments have reassessed the relationship between tax hikes and capital flight as their information exchange relationships with other governments intensified. Against the background of the theoretical considerations discussed above, we hypothesize that the positive effect of domestic political and functional drivers (compensatory fairness concerns, governing party ideology, capital/labor tax ratio and budget deficits) on the tax rate an OECD country imposes on dividends at the shareholder level is conditional on the level of financial transparency in its investment network (H1). At the same time, an increase in financial transparency in an OECD country’s investment network does not have a direct effect on the tax rate it imposes on dividends (H2) since information exchange agreements do not coordinate tax rates.

To test our hypotheses, we first introduce the INTS, an original financial transparency indicator, which is based on a qualitative analysis of all relevant information exchange agreements and a network analysis of all OECD countries' portfolio investment relationships in every year 
from 2001 to 2018. We then operationalize domestic political and functional pressures and run regression analyses on cabinets’ dividend tax rate choices.

\section{The Evolution of Financial Transparency}

\subsection{The Politics of Expanding Information Exchange}

According to established international rules and most OECD countries’ national tax laws, individuals and households are taxable on their worldwide income at their place of primary residence. To deter taxpayers from tax evasion, most OECD governments made the non-declaration of (foreign) income a criminal offense and included information exchange clauses in bilateral double taxation agreements (DTAs). But these clauses have four important loopholes, which are susceptible to prevent a reliable flow of information on taxpayers' foreign accounts. (1) They provide for information exchange on request. Hence, the tax authority demanding information has to submit a separate inquiry for every individual it suspects of tax evasion, including initial evidence substantiating the suspicion (Eccleston, 2012, p. 96). In their original version, (2) the clauses also allowed signatories to decline requests when they did not collect desired information for domestic tax purposes (Rixen, 2008, p. 75). And even if a request was granted under these restrictive circumstances, (3) first generation DTAs did not oblige banks to look through interposed legal entities when identifying account owners. Accordingly, wealth managers could hide clients behind trusts or shell companies to preclude the reporting of their accounts (Levin and Coleman, 2006, p. 316; Harrington, 2016). Finally, (4) the clauses do not provide signatories with a legal enforcement mechanism. If a treaty partner does not fulfil its obligations, they can merely launch a mutual agreement procedure or suspend the DTA (cf. OECD, 2017).

By reducing the risk of detection, these loopholes made offshore tax evasion popular (Palan et al., 2010). In fact, recent studies suggest that offshore wealth amounted to 10 percent of world 
GDP in the early to mid-2000s, 80 to 90 percent of which had not been declared to tax authorities (Alstadsæter et al., 2018; Alstadsæter et al., 2019). The magnitude of these numbers and recurrent tax evasion scandals motivated residence countries to improve information exchange standards (Eccleston, 2012, p. 63; Emmenegger, 2015). In a first step, the OECD addressed loopholes 2 and 3 by publishing a model Agreement on Exchange of Information on Tax Matters in 2002. The model prevents signatories from declining requests simply because desired information is held by a financial institution, and obliges them to collect and exchange beneficial ownership data on trusts, foundations and other interposed legal entities (OECD, 2002, p. 7). In 2005, these safeguards were also included in the OECD’s general model tax agreement (MTA) (OECD, 2017, p. 487).

But success in striking corresponding agreements with tax havens varied significantly between member states. The US Treasury benefitted from its unmatched financial market power in concluding Tax Information Exchange Agreements (TIEAs) with most Caribbean tax havens from 2001 (Rixen, 2008, p. 139). In contrast, not even the remaining G7 members managed to strike such agreements with secrecy jurisdictions in their investment networks before 2009 . That year, OECD members Austria, Luxembourg and Switzerland bowed to coordinated pressure from the G20 and dropped their reservations against the 2005 revision of the MTA (Johannesen and Zucman, 2014, pp. 69-70).

In parallel to improving the OECD’s on request standard, some member states also addressed loophole 1 and introduced automatic information exchange mechanisms through regional and unilateral initiatives. In an agreement that was unique at the time, the Nordic countries had already agreed in 1989 to automatically inform each other of wage, dividend and interest payments to their respective residents (Valkama, 2013). The US Treasury introduced the Qualified Intermediary (QI) program in 2000, which obliged foreign banks to routinely report American clients receiving payments from the United States, but did not provide for similar reporting from US banks to foreign tax authorities (Government Accountability Office, 2007). 
Finally, EU finance ministers adopted the Savings Tax Directive (STD) in 2003, which provided for an AEoI on interest payments to non-residents but granted secretive member states an opt-out. As long as non-members Liechtenstein and Switzerland did not comply with the OECD's on request standard, Austria, Belgium and Luxembourg could transfer the proceeds of a small withholding tax on interest payments instead of reporting recipients to other EU countries (Sharman, 2008). But all initial AEoI programs suffered from the lack of an explicit obligation to identify the beneficial owners of a bank account (3), and the QI and STD merely applied to some types of capital income (5). This fifth loophole allowed wealth managers to circumvent the reporting of their clients by stripping their portfolios of securities that produced either US-source or interest income (Government Accountability Office, 2007; Rixen and Schwarz, 2012).

These deficiencies became politically highly salient when two tax evasion scandals involving Liechtenstein Global Trust (LGT) and Union Bank of Switzerland (UBS) broke in early 2008. In both cases, policymakers used information provided by whistleblowers on their former employers' circumvention of reporting obligations under the STD and QI program to raise support for more far reaching transparency initiatives (Eggenberger and Emmenegger, 2015, p. 494). France and Germany used the momentum to put financial transparency on the G20's financial crisis reform agenda. In April 2009, the group declared the end of banking secrecy and threatened jurisdictions that did not comply with the 2005 revision of the OECD’s MTA with economic sanctions (Johannesen and Zucman, 2014, p. 69). This threat motivated Austria, Luxembourg and Switzerland to comply with the OECD's on request standard, which paved the way for revisions of the EU's Directive on Administrative Cooperation (DAC 1) and the STD. Through the adoption of DAC 1, EU finance ministers transposed the OECD’s model Agreement on Information Exchange into EU law, thereby bringing it under the jurisdiction of the European Court of Justice (ECJ) and closing loophole 4 (cf. European Union, 2011). Moreover, Swiss compliance removed one of the key justifications for the opt-out the STD granted to 
Austria and Luxembourg, providing other member states with a first lever to request an extension of the AEoI to the entire EU and to all types of capital income (Hakelberg, 2015, p. 413).

Like the governments of France and Germany, also the Obama administration drew lessons from the LGT and UBS scandals and developed legislation removing loopholes 3 and 5 from the QI program’s reporting requirements. In March 2010, congress passed the Foreign Account Tax Compliance Act (FATCA), obliging foreign banks to automatically report US clients and their entire capital income irrespective of the legal structures through which they hold their accounts. Incompliant banks face a 30\% withholding tax on most payments from the United States (Grinberg, 2012). Because many banks would have broken domestic law by reporting account information directly to the US government, they lobbied their home governments to conclude intergovernmental agreements (IGAs) for the implementation of FATCA with the US Treasury. These IGAs became legal precedents committing signatories to the principle of AEoI on all forms of capital income. Hence, arguments against the AEoI with third countries became increasingly dubious after their adoption. The G20 seized the opportunity, endorsing AEoI as the new global standard for administrative assistance in tax matters and tasking the OECD to develop a common reporting standard (CRS) based on FATCA (Emmenegger, 2017).

In October 2014, the CRS was eventually adopted by multilateral agreement and is currently practiced by more than 100 jurisdictions worldwide, including all traditional tax havens. Likewise, Austria and Luxembourg's acceptance of AEoI with the United States enabled other EU member states to break their opposition to the material and geographic expansion of the STD, preparing the ground for the transposition of the CRS into EU law by a 2014 update of the Directive on Administrative Cooperation (DAC 2). A notable exception is the United States, which has not signed the multilateral agreement on CRS implementation and does not fully reciprocate the AEoI through its FATCA IGAs (Hakelberg and Schaub, 2018). Still, the adop- 
tion of the CRS has not precipitated a larger increase in foreign deposits and portfolio investments in the United States than in other large developed economies, most likely because the US Treasury implements rather comprehensive on request agreements with key allies.

Previous research demonstrates that the legal instruments discussed above increased the risk of detection perceived by tax evaders, thereby altering their investment decisions. Because TIEAs and the STD do not require foreign banks to identify the beneficial owners of interposed legal entities (loophole 3), their adoption mainly caused international banks to hide their clients behind offshore shell companies (Johannesen and Zucman, 2014; Johannesen, 2014; Omartian, 2017). Still, the US government had some success in reducing round-tripping by US investors and raising additional tax revenue through the adoption of TIEAs with tax havens (Hanlon et al., 2015; Johannesen et al., 2018). Most strikingly, the introduction of the AEoI through FATCA, DAC 2 and the CRS led to a substantial reduction in tax evasion. Relying on incorporation data from Mossack Fonseca made available through the Panama Papers leak, Omartian (2017, p. 4) shows that the introduction of FATCA led to a 30\% decline in the incorporation of shell companies by US investors. Likewise, agreement on DAC 2 in the Council of the EU made closures of shell companies, which had been set up in response to the introduction of the STD, two to five times more likely than closures of other shell companies. Finally, Ahrens and Bothner (2019, p. 13) find that the value of financial assets held by households in tax havens is 67 percent lower today than in a counterfactual scenario without FATCA and the CRS.

In sum, compared to the regulatory situation in 2008, hiding financial wealth in offshore accounts had become a lot more risky by 2018. Accordingly, there should be a concomitant reduction in the risk of capital flight faced by OECD governments. Importantly, however, the process leading towards the adoption of the CRS was beyond the control of most OECD member states. Whereas the US government could shape international rules in accordance with domestic priorities, all remaining governments had to seize opportunities provided by decisive US action to obtain more comprehensive information from secrecy jurisdictions. As the subsequent 
section will show, the ability of OECD countries to cover their investment networks with AEoI relationships still varies considerably. With the exception of the United States, it is thus highly unlikely that the desire to increase taxes on capital income is enough to increase the level of financial transparency in the investment networks of OECD members. Rather, exogenous factors like major tax scandals and US domestic politics have shaped this outcome (Hakelberg, 2020).

\subsection{The Investment Network Transparency Score}

To operationalize the uneven expansion of information exchange discussed above, we proceed in two steps. First, we determine how many of the five loopholes are closed by each of the agreements discussed above. For each loophole closed, we allocate one point to the agreement, which can thus obtain a score from 0 (=totally ineffective) to 5 (=highly effective). Table 1 summarizes how the different information exchange agreements perform on our coding scheme.

[Table 1: Coding scheme for information exchange agreements]

Second, we use network analysis on data from the International Monetary Fund's (IMF) Coordinated Portfolio Investment Survey (CPIS) to identify the crucial nodes in each OECD country's investment network in every year under study (see the online appendix for a detailed discussion). This enables us to identify which of the bilateral relationships within the core of the resulting ego networks are governed by what information exchange agreements. Countries in the core have intense reciprocal investment relationships with the country under study as well as with other important nodes in that country's investment network. Hence, they are likely to be the most important conduits in global wealth chains beginning or ending in that country (Seabrooke and Wigan, 2017). 
Since OECD governments usually replace less comprehensive on request or AEoI agreements with more comprehensive ones but implement on request and AEoI agreements in parallel, we cumulate the scores for the latest on request and AEoI agreements that have been adopted in a given year. Hence, when Norway modernized its DTA with Luxembourg in 2009, the score for this relationship increased from 1 to 3 because the modernized DTA superseded the traditional DTA. When Luxembourg agreed to practice the CRS in 2014, however, the score increased from 3 to 7 as the DTA and the CRS now operate in parallel. We count agreements from their year of adoption as previous research has shown that investors adjust their behavior to a new regulatory situation already at this point in time (Ahrens and Bothner, 2019; Hakelberg and Schaub, 2018). The average score across all bilateral relationships in a given ego network and year becomes the INTS.

[Figure 2: Development of the INTS over time]

Figure 2 shows the INTS for the 35 OECD countries between 2001 and 2018 including a year-specific average. It becomes evident that transparency has increased substantially from an average of 1.2 in 2001 to an average of 6.8 in 2018, which is a direct consequence of the expansion of information exchange discussed in the previous section. Since other established indicators of financial secrecy/transparency are not comparable across time, owing to methodological changes (e.g. Cobham et al., 2015), the INTS offers the first quantitative reflection of this trend. However, the indicator also reveals remarkable cross-country variation in financial transparency. As the blue circles in Figure 2 illustrate, the INTS varied between 0.5 and 5.3 in 2008 and between 1 and 9 in 2018 (see Figure A3 in the online appendix for exemplary country time series showing how the different legal instruments feed into the scores). This reflects the diverging ability of OECD member states to apply international information exchange standards in their bilateral tax treaties. The dominance of the US financial market enabled the US 
Treasury already at the beginning of the observation period to obtain information on US taxpayers from banks across the world. The Nordic and EU countries have benefitted from a relatively high level of mutual assistance over the entire observation period but failed to extend their cooperation to particularly secretive European countries until the US applied decisive pressure. In contrast, non-EU members still struggle to activate CRS relationships with dominant nodes in their investment networks, particularly the United States (Chile, Israel, Korea), or refuse to apply the standard themselves (Turkey).

[Figure 3: Capital taxation and financial transparency]

A similar pattern emerges when we compare the evolution of the INTS and dividend tax rates across OECD countries. In line with our expectation that more transparent investment networks enable governments to raise taxes, Figure 3 reveals a remarkable correlation $(r=.73)$ between the aggregate series of both variables. Likewise, the scatterplot of transparency and the intra-country development of dividend tax rates depicted in Figure 4 suggests that states benefitting from higher transparency are more likely to increase their tax rates. It thus seems to make a difference whether policymakers perceive the risk of capital flight as high or low. At the same time, however, the individual data points in the scatterplot reveal a high degree of variation around the fitted line. While most countries increased tax rates as transparency increased, many countries developed along vastly different paths. Some countries lowered taxes in a context of high transparency, while others raised taxes also in very secretive environments. Accordingly, transparency alone cannot explain all of the observed variation. Instead, domestic politics and functional pressures are likely to provide the initial impetus for tax rate changes, whereas the level of transparency conditions whether they are implemented. How exactly driving and enabling factors interact in producing tax rate increases is the topic of the next section. 
[Figure 4: Scatterplot of de-meaned tax rates and financial transparency]

\section{Method and Data}

Tax rate adjustments follow political decisions by governments. To test our hypotheses, we thus model tax reforms using a cabinet-based periodization (Garritzmann and Seng, 2016; Schmitt, 2016; Schmitt and Zohlnhöfer, 2018). We estimate regression models using cabinets as the unit of analysis and tax rate changes during their incumbency as the dependent variable. This specification should be preferred over conventional TSCS models using country-years as the unit of observation, as cabinet periodization conforms to how political decisions over tax rates are implemented from a theoretical standpoint, namely by governments during their incumbency. In contrast, pooled time series models using country-years disregard the reality of political decision making. Governments do not assess each and every year whether the international context and domestic drivers now warrant tax reforms. Especially in coalition governments, such reforms require considerable political transaction costs that are unlikely to be borne several times during a single sitting cabinet.

Furthermore, using country-years assumes a strictly homogenous lag structure of the effects of all independent variables. Most studies assume a one-year lag, which implies, for instance, that the level of financial transparency in year $t-1$ only affects tax rates in $t$. However, such assumptions lead to mis-specified models because (a) there is no theoretical guidance on how the lag structure should be set up, and (b) because it is unreasonable to assume that all governments take exactly the same amount of time to react to a change in transparency (Garritzmann and Seng, 2016, p. 513). While one government may increase taxes on dividends immediately after investiture, another government may delay the reform until a later point during incumbency because unforeseen matters require immediate attention or because coalition partners agreed on a particular order of doing things. As Plümper et al. (2005) show, such differences in 
dynamics introduce considerable bias in effect estimates with conventional time-series crosssection data. In contrast, using cabinets as the unit of analysis resolves this problem because tax policy reforms at any point in time during a government's incumbency are taken into account.

We define cabinets as governments with the same party composition over a given amount of time. A new cabinet begins once the share of portfolios controlled by each governing party changes. While this criterion is in principle independent of elections, it coincides with them most of the time. The start and end years of cabinets are based on the dates of investiture and dismissal so that a cabinet that took office at any point in time during 2015 and left office at any point in time during 2018 is coded as being in office from 2015 to $2018 .^{2}$ Cabinets in power for less than one year during our observation period are excluded since "short-term cabinets such as caretaker governments are typically not able to quickly implement policies” (Schmitt, 2016, p. 1452). The data on cabinets are gathered from the government composition supplement to the Comparative Political Data Set (CPDS) (Armingeon et al., 2018). Since data is only available until 2016 and does not cover OECD members Chile, Israel, Mexico, South Korea and Turkey, we supplement missing cabinets and partisan compositions following instructions in the CPDS codebook.

We use changes in the dividend tax rate between the first and last year of a cabinet as the dependent variable. Our data source is the item "net personal tax" from the OECD tax database’s table II.4 (OECD, 2019a), which “shows the net top statutory rate to be paid at the shareholder level, taking account of all types of reliefs and gross-up provisions at the shareholder level.” That is, the tax rate households pay on their dividend income. Along with the average INTS during a cabinet's incumbency, which is our main independent variable, we include proxies for the political and functional drivers of tax policy change identified in section 2 in our regression models. To approximate a government's ideological leaning, we use the CPDS indicator reflecting the share of left ministers in a country's cabinet. We measure budget deficits with OECD data on member states’ public budget balances defined as public revenue minus 
public spending as a proportion of GDP (OECD, 2019b). However, since the budget balance is likely to be affected by the dividend tax rate, we use the average value over the first half of a cabinet's term to avoid endogeneity problems (Schmitt, 2016, p. 1452). ${ }^{3}$

To approximate fairness concerns we rely on two indicators. First, we emulate Limberg's (2018; 2019) approach, which is based on the insight that financial crises raise voter demand for compensatory fairness and include the binary crisis indicator developed by Laeven and Valencia (2013). ${ }^{4}$ Since financial crises also exacerbate budget deficits by forcing governments to finance bail-outs of failing banks and stimulus packages for the real economy, however, the indicator may not provide the best approximation of fairness concerns. Therefore, following Ganghof (2006), we include an additional fairness proxy. To measure the politically salient tax privilege enjoyed by capital over labor income we use the ratio between the net tax rate on dividends and the top marginal income tax rate. Data on top marginal income tax rates also come from the OECD Tax Database. Whereas the crisis indicator takes on the value of one if a financial crisis occurred at any point during a cabinet's incumbency, data on tax ratios is averaged over the first half of the cabinet's tenure since they crucially depend on the dividend tax rate.

In addition, we include two control variables to control for considerations of tax system design. First, we use changes in the top marginal income tax rate. In countries that have not opted for a dual or differentiated income tax system, the taxation of dividends at the shareholder level remains part of general personal income taxation and may thus be shaped by the development of the personal income tax (Ganghof, 2006). Hence, there is a possibility that governments eager to increase the tax burden on high labor incomes increase the tax burden on capital income in passing rather than on purpose. Second, we include changes in the corporate tax rate to control whether cabinets only raise taxes on dividends to shift the overall tax burden on capital from corporations to shareholders. According to the new view on capital taxation, a corresponding shift may improve the tax system's efficiency since the financing costs of domestic firms, 
which can source loans and investment from anywhere in the world, no longer depend on the domestic tax rate on interest and dividends (Brys et al., 2016).

Furthermore, we include three controls for the main variables in research on tax policy, including the size of the tax state, tax structure, and economic performance (cf. Kiser and Karceski, 2017; Martin et al., 2009). To check whether the likelihood of an increase in dividend taxation varies with the size of the tax state, we use tax revenue as a percentage of GDP. To check whether countries, which are more reliant on direct than on indirect taxation, are more likely to raise taxes on income from dividends, we include income tax revenue as a percentage of overall revenue. And to check whether the likelihood of increases in dividend taxation varies with overall economic performance, we use GDP per capita (logged). Finally, we control for cabinet duration in days (logged) ${ }^{5}$ because longer cabinets have increased opportunity to implement reforms (Schmitt, 2016). Descriptive statistics for all variables are available in Table A2 in the online appendix.

\section{Results and Discussion}

Table 2 reports the results of several regression models based on 204 cabinets observed in all 35 OECD countries between 2001 and 2018. All models are estimated with conventional standard errors. ${ }^{6}$ Model 1 includes the theoretically relevant variables as well as all control variables. In line with H2, the result shows that transparency does not have an independent effect on dividend tax rates. This reflects that information exchange agreements do not provide for a coordination of tax rates. They merely define the conditions under which information on taxpayers' foreign accounts is accessible to domestic tax authorities. Accordingly, governments are unlikely to raise the dividend tax rate just because the level of transparency has increased. We only expect corresponding reforms once a political or functional driving factor coincides with a high level of transparency. Therefore, we introduce interaction terms between the INTS and each of the respective proxies in models 2 to 5 . 
[Table 2: Effects on cabinets' changes of dividend tax rates]

The result of model 2 reveals that left cabinets are not more likely than conservative or liberal cabinets to raise taxes on dividends, irrespective of the level of financial transparency. This is an intriguing result since, ceteris paribus, cabinet periodization usually yields a larger party effect than a country-year specification (Schmitt, 2016). The absence of partisan differences may reflect the structural constraint of tax competition under low transparency (Genschel, 2002) or the commitment of left parties to corporatist bargains that trade in redistribution on the spending side for capital relief on the revenue side (Beramendi and Rueda, 2007). Model 3 includes an interaction term between transparency and budget balance instead. The interaction coefficient is negative and significant at the $5 \%$ level. That is, negative budget balances (i.e. more pronounced deficits) in combination with higher transparency motivate cabinets to increase taxes on dividends. This confirms our expectation. High transparency reduces the risk of capital flight. Accordingly, governments can expect additional revenue from a tax increase on dividends when transparency in their investment network is high. The conditionality of budget deficits on transparency may explain why Lierse and Seelkopf (2016) do not find a direct effect of deficits on mobile tax bases in most of their model specifications.

Models 4 and 5 test the interaction between transparency and fairness concerns. The result for model 4 reveals that governments facing a deep banking crisis are not more likely than other governments to raise taxes on dividends, irrespective of the level of transparency. Likewise, the results for model 5 indicate that low transparency does not prevent governments from addressing the unequal treatment of capital and labor income during their incumbency. Instead, the large and highly significant negative effect of the capital/labor tax ratio suggests that a larger tax privilege for capital over labor income at the beginning of a term (reflected in a lower dividend tax rate relative to the top marginal income tax rate) always makes sitting governments 
more likely to raise the tax rate on dividends by the end of their incumbency. Apparently, the rather visible discrimination of labor income and the risk of domestic tax avoidance linked to the beneficial treatment of capital income are enough motivation for many governments to close the gap between the two tax rates. The risk of capital flight seems to be of secondary concern, potentially because governments are content with signaling equal treatment to voters through an adjustment of statutory tax rates. A corresponding move under low transparency could reestablish the perceived fairness and coherence of the domestic tax system without actually increasing the contribution of capital to overall tax revenue. Hence, governments may be exploiting voters’ fiscal illusion about other people’s tax burdens.

Finally, results for our control variables, which are constant across the five models, yield mixed results. First, the dividend tax rate does coevolve with the top marginal income tax rate. This is unsurprising since the taxation of dividends at the shareholder level is integrated with the personal income tax in synthetic tax systems. Second, the coefficient for the variation in corporate tax rates points in the expected direction but does not reach conventional levels of statistical significance. As it seems, the new view on capital taxation has not motivated OECD governments to raise taxes on dividends to compensate tax cuts on corporate profits. Third, the coefficient for cabinet duration reaches conventional levels of statistical significance in 2 out of 5 models. Its negative sign suggests that older governments tend to have lower tax rates than younger governments.

In sum, results for the interaction terms partially support H1. When budget deficits are a government's primary concern, financial transparency enables tax increases on the mobile tax base of capital income. When the revenue yield of a tax increase on capital income is not a government's focus, however, transparency makes no difference. The reason is most likely that governments want to signal equal treatment to voters by adjusting the dividend to the top marginal income tax rate, irrespective of the effect such reform has on the actual division of the tax burden between capital and labor. 
Figure 4 plots our main result, the interaction effect of budget balance and transparency. We present the effect of transparency conditional on budget balance instead of the effect of budget balance conditional on transparency. This allows us to assess whether transparency only plays a role when governments experience budget deficits, which we expect since transparency neither constrains nor enables tax rate cuts. As such, the graph reflects that governments with budget deficits make use of the additional room to maneuver and increase tax rates when they benefit from transparent investment networks. This lends support to H1. ${ }^{7}$ As a practical illustration of the estimated effect strength, consider Shinzo Abe's third cabinet, which took office in 2014, the year the CRS was first implemented. The cabinet experienced medium-to-high financial transparency (5 on the INTS index) and had an initial budget deficit of 4.11\% of GDP. The model expects a tax raise of $0.7 \%$ percentage points. If transparency were to rise to 6 , the expected tax raise increases to $1.1 \%$; and if instead the deficit were to increase by one percentage point, it increases to $0.9 \%$.

[Figure 5: Effect of transparency conditional on budget balance]

We estimate several additional models with alternative specifications to assess the robustness of our main results (see the online appendix, Table A3). We first assess our conceptualization of transparency. The modeling approach assumes that transparency uniformly affects policymaking even though, e.g., moving from the value 2 to 3 on the index may entail qualitatively different changes in international tax cooperation compared to moving from 5 to 6 . To gauge the robustness of our results, we rely on a categorical variable instead of the INTS index. The variable categorizes cabinets into three groups based on the stage in the development of financial transparency during which they held office. The first group includes cabinets that ended their term before 2009. The second group includes cabinets that ended their term between 2009 and 2013, i.e. the period after the OECD famously proclaimed the 'end of bank secrecy' and 
pushed for the adoption of TIEAs; and the third group includes cabinets that ended between 2014 and 2018, when the CRS was implemented. Figure 6 depicts the main result of the regression (full results are available in Table A3).

[Figure 6: Predicted tax rate changes by cabinet period and budget balance]

Figure 6 confirms our initial findings. Relative to the baseline period (before 2009), cabinets that ended their term in the second (2009-2013) and third (2014-2018) period have higher predicted tax rate changes. However, this only pertains to cabinets with budget deficits. Moreover, predicted tax rate increases are larger and have improved statistical significance in the postCRS period. Although we would have expected the estimated coefficient to be even larger in the third period compared to the second, this reflects the advances in financial transparency during the post-CRS period. Overall, we argue that our INTS indicator offers the superior modeling approach because it relies on a fine-grained measurement of both cross-sectional and temporal variation in countries' coverage with tax treaties. But Figure 6 confirms that our results also hold when a categorical variable is used instead. Irrespective of assumptions about scale and functional form of financial transparency, governments that experience budget deficits increase tax rates on dividends in times of increased transparency.

As a further robustness check, model 2 uses changes in transparency instead of the average level because governments may react to shifts in financial transparency rather than the absolute level. We prefer the levels-specification, as it better reflects the notion of transparency as an enabling factor. But the results show that it does not make a difference which specification is chosen. Model 3 uses country dummies and Model 4 period dummies (cabinet ended before '05, ‘05-’07, '08-'10, '11-'13, '14-'16 or '17-'18) to exclude that cabinets raised tax rates as a reaction to country- or period-specific influences. The results are almost identical. Especially Model 4 using period dummies is promising because it shows that our results are not driven by 
a mere coincidence of rising dividend tax rates and a strong upward trend in financial transparency (i.e. spurious correlation between two upwards-trending variables). Furthermore, Model 5 uses country-clustered standard errors. Our main models rely on model-based standard errors because statistical tests suggest that clustered errors are not necessary. ${ }^{8}$ However, the results are confirmed when using clustered errors instead.

The remaining robustness checks tackle possible endogeneity due to simultaneity or reverse causality. We acknowledge that the variables in our models have causal relationships that go beyond the assumed unidirectionality (e.g., the level of dividend taxes clearly affects the countries’ budgets). To avoid this kind of endogeneity, we used first-half averages for most independent variables. To further reduce the risk of endogeneity, we instead rely on first-year levels in Model 6. Lastly, Model 7 drops the remaining candidates for endogenous variables, i.e. cabinet-specific changes of the top marginal and corporate income tax rate. The results show that both specifications lead to unchanged results.

\section{Conclusion}

The increase in financial transparency over the past decade has contributed to the upward trend in dividend taxation observed across the OECD since 2008. By reducing the risk of capital flight, financial transparency enabled cash-strapped governments to raise additional revenue through tax increases on an otherwise highly mobile tax base. Sophisticated information exchange agreements provided OECD countries with new room to maneuver in the taxation of capital income. In the absence of fiscal pressure, however, financial transparency had no impact on dividend taxation. An independent effect of transparency on taxation is unlikely since information exchange agreements do not dictate tax rates to treaty partners. Hence, no government raises the dividend tax rate just because of an increase in financial transparency. In contrast, the absence of an interaction effect between transparency and fairness concerns comes as a theo- 
retically interesting surprise. Tax systematic biases against labor income have motivated governments to raise tax rates on dividends at the shareholder level, irrespective of the associated risk of capital flight. In a context of low transparency, governments are apparently content with signaling equal treatment of income types to voters. Whether the adjustment of tax rates leads to an actual shift of the tax burden towards capital seems to be of secondary concern.

These findings also inform a more general debate in comparative political economy on the relative importance of domestic and international drivers of tax policy change. Whereas previous contributions to this debate either defended the preeminence of domestic over international factors or the opposite (e.g. Genschel, 2002; Plümper et al., 2009), our findings raise the possibility of equifinality. As it seems, mitigating the structural constraint of tax competition through information exchange enables governments to respond to some domestic drivers of tax increases like severe budget constraints. In this case, the government's main policy goal is additional revenue. Therefore, the risk of capital flight is a relevant constraint. When a government's main policy goal is the defense of the tax system's perceived fairness, however, this is a secondary concern. Accordingly, voter demand for an equal treatment of income types may produce tax increases on mobile tax bases irrespective of the degree of competitive pressure emanating from the international level. If we want to develop reasonable expectations about the impact of domestic and global factors on national tax policy, we thus need to better understand the political goals governments want to achieve through tax reforms.

Finally, our findings suggest that the impact of international tax cooperation on cross-border flows and stocks of capital (cf. Johannesen, 2014; Johannesen and Zucman, 2014) is not the only approach towards measuring its effectiveness. Since the goal of countermeasures to tax evasion and avoidance is to ensure that everyone pays their fair share of tax, these measures' impact on national tax rates should also reflect whether they function as intended. Future assessments should therefore combine an analysis of cross-border capital flows, measuring the degree of taxpayer arbitrage, with an analysis of national tax rates and potentially tax revenue, 
reflecting the extent to which national governments enjoy greater room to maneuver in the taxation of capital as a result of international cooperation. As our results show, international cooperation does not limit national sovereignty as many right-wing populists claim. To the contrary, done right, it restitutes national sovereignty previously lost to the structural constraints and functional demands of economic globalization. 


\section{Notes}

${ }^{1}$ Since the capital share in personal income rises with its size, top marginal income tax rates are often used as a proxy for the taxation of mobile tax bases (cf. Lierse and Seelkopf, 2016, p. 152)

${ }^{2}$ We opt against Schmitt's (2016) approach of allocating the values for the post-transition year to the outgoing government if it took office after 1 July. This is because (a) we assume that the likelihood of tax reform decreases with cabinet duration, and (b) because we already rely on end-of-year data. Therefore, we believe that the risk of unduly allocating a tax rate change to an outgoing government by extending cabinet duration by one year is higher than the risk of unduly allocating this change to the incoming government.

${ }^{3}$ If cabinets governed for an uneven number of years, we use the value of the first year (3year governments) or the average value of the first two years (5-year governments).

${ }^{4}$ The indicator of Laeven and Valencia indicates a crisis if, after the beginning of the financial crisis in 2007 (US, UK) or 2008 (other countries), countries experienced a sustained economic contraction and credit freeze. Crises are hand-coded to be no longer than 5 years and they are wholly absent in a number of countries.

${ }^{5}$ GDP per capita and cabinet duration are both log-transformed so that they approximate a normal distribution since both are heavily skewed from top-end outliers.

${ }^{6}$ We opt against the usual approach of using country-clustered standard errors because statistical tests suggest that there is no reason to do so. Wooldridge tests detect no country-specific autocorrelation and Breusch-Pagan tests detect no heteroskedasticity in any of our models. However, a robustness check uses clustered errors. 
${ }^{7}$ The marginal effects plot also shows that transparency significantly decreases tax rates under very large budget surpluses, but this only conforms to $2 \%$ of our observations (4 out of 204).

${ }^{8}$ As outlined above, Breusch-Pagan and Wooldridge tests detect neither heteroskedasticity nor serial correlation in any of our initial models. 


\section{References}

Ahrens, L. and Bothner, F. (2019) 'The Big Bang: Tax Evasion After Automatic Exchange of Information Under FATCA and CRS', New Political Economy, 0, 1-16.

Alstadsæter, A., Johannesen, N. and Zucman, G. (2018) 'Who Owns the Wealth in Tax Havens? Macro Evidence and Implications for Global Inequality’, Journal of Public Economics, 162, 89-100.

Alstadsæter, A., Johannesen, N. and Zucman, G. (2019) 'Tax Evasion and Inequality’, American Economic Review, 109, 2073-2103.

Armingeon, K., Isler, C., Knöpfel, L., Weisstanner, D. and Engler, S. (2018) 'Comparative Political Data Set’, accessed at http://www.cpds-data.org/ on March 20, 2017.

Basinger, S. J. and Hallerberg, M. (2004) 'Remodeling the Competition for Capital: How Domestic Politics Erases the Race to the Bottom', The American Political Science Review, 98, 261-276.

Beramendi, P. and Rueda, D. (2007) 'Social Democracy Constrained: Indirect Taxation in Industrialized Democracies’, British Journal of Political Science, 37, 619-641.

Brys, B., Perret, S., Thomas, A. and O’Reilly, P. (2016) Tax Design for Inclusive Economic Growth, OECD Taxation Working Papers, Paris, Organisation for Economic Co-operation and Development.

Cobham, A., Janský, P. and Meinzer, M. (2015) 'The Financial Secrecy Index: Shedding New Light on the Geography of Secrecy’, Economic Geography, 91, 281-303.

Creighton, A. (2016) ‘A Shrinking World Spurs Calls to Rewrite the Tax Guidebook’, WSJ.

Eccleston, R. (2012) The Dynamics of Global Economic Governance: The OECD, the Global Financial Crisis and the Transformation of International Tax Regulation, Edward Elgar Publishing.

Eggenberger, K. and Emmenegger, P. (2015) 'Economic Vulnerability and Political Responses to International Pressure: Liechtenstein, Switzerland and the Struggle for Banking Secrecy', Swiss Political Science Review, 21, 491-507.

Emmenegger, P. (2015) 'The Long Arm of Justice: U.S. Structural Power and International Banking', Business \& Politics, 17, 473-493.

Emmenegger, P. (2017) 'Swiss Banking Secrecy and the Problem of International Cooperation in Tax Matters: A Nut Too Hard to Crack?’, Regulation \& Governance, 11, 24-40.

European Union (2011) 'Council Directive 2011/16/EU of 15 February 2011 on Administrative Cooperation in the Field of Taxation and Repealing Directive 77/799/EEC', Official Journal, 54, 1-12.

Ganghof, S. (2006) The Politics of Income Taxation: A Comparative Analysis, ECPR Press. 
Garrett, G. and Mitchell, D. (2001) 'Globalization, Government Spending and Taxation in the OECD’, European Journal of Political Research, 39, 145-177.

Garritzmann, J. L. and Seng, K. (2016) 'Party Politics and Education Spending: Challenging Some Common Wisdom’, Journal of European Public Policy, 23, 510-530.

Genschel, P. (2002) 'Globalization, Tax Competition, and the Welfare State', Politics \& Society, 30, 245-275.

Genschel, P. and Schwarz, P. (2011) 'Tax Competition: A Literature Review', Socio-Economic Review, 9, 339-370.

Government Accountability Office (2007) 'Tax Compliance: Qualified Intermediary Program Provides Some Assurance That Taxes on Foreign Investors Are Withheld and Reported, but Can Be Improved', accessed at http://www.gao.gov/products/GAO-08-99 on November 24, 2014.

Grinberg, I. (2012) 'Beyond FATCA: An Evolutionary Moment for the International Tax System’, Georgetown Law Faculty Working Papers.

Hakelberg, L. (2015) 'The Power Politics of International Tax Co-Operation: Luxembourg, Austria and the Automatic Exchange of Information', Journal of European Public Policy, 22, 409-428.

Hakelberg, L. (2020) The Hypocritical Hegemon: How the United States Shapes Global Rules Against Tax Evasion and Avoidance, Ithaca, N.Y., Cornell University Press.

Hakelberg, L. and Rixen, T. (2017) 'Is Neoliberalism Still Spreading? The Impact of International Cooperation on Capital Taxation'. In Fighting Tax Avoidance and Tax Crimes in the European Union, University of Oslo.

Hakelberg, L. and Schaub, M. (2018) 'The Redistributive Impact of Hypocrisy in International Taxation', Regulation \& Governance, 12, 353-370.

Handelsblatt (2006) 'Steinbrück Will Mit 25 Prozent Einsteigen’, accessed at http://www.handelsblatt.com/politik/deutschland/abgeltungssteuer-steinbrueck-will-mit-25-prozenteinsteigen/2708232.html on August 21, 2014.

Hanlon, M., Maydew, E. L. and Thornock, J. R. (2015) 'Taking the Long Way Home: U.S. Tax Evasion and Offshore Investments in U.S. Equity and Debt Markets', The Journal of Finance, 70, 257-287.

Harding, M. and Marten, M. (2018) 'Statutory Tax Rates on Dividends, Interest and Capital Gains'.

Harrington, B. (2016) ‘Trusts and Financialization’, Socio-Economic Review, 15, 31-63.

Johannesen, N. (2014) 'Tax Evasion and Swiss Bank Deposits', Journal of Public Economics, 111, 46-62.

Johannesen, N., Langetieg, P., Reck, D., Risch, M. and Slemrod, J. (2018) Taxing Hidden Wealth: The Consequences of U.S. Enforcement Initiatives on Evasive Foreign Accounts, Working Paper, National Bureau of Economic Research. 
Johannesen, N. and Zucman, G. (2014) 'The End of Bank Secrecy? An Evaluation of the G20 Tax Haven Crackdown’, American Economic Journal: Economic Policy, 6, 65-91.

Kiser, E. and Karceski, S. M. (2017) 'Political Economy of Taxation', Annual Review of Political Science, 20, 75-92.

Laeven, L. and Valencia, F. (2013) 'Systemic Banking Crises Database', IMF Economic Review, 61, 225-270.

Levin, C. and Coleman, N. (2006) Tax Haven Abuses: The Enablers, the Tools, and Secrecy, Washington, US Senate.

Lierse, H. and Seelkopf, L. (2016) 'Room to Manoeuvre? International Financial Markets and the National Tax State', New Political Economy, 21, 145-165.

Limberg, J. (2018) 'What's Fair? Preferences for Tax Progressivity in the Wake of the Financial Crisis', Journal of Public Policy, 1-23.

Limberg, J. (2019) ““Tax the Rich”? The Financial Crisis, Fiscal Fairness, and Progressive Income Taxation', European Political Science Review: EPSR, Online First.

Martin, I. W., Mehrotra, A. K. and Prasad, M. (2009) The New Fiscal Sociology: Taxation in Comparative and Historical Perspective, Cambridge University Press.

OECD (2002) Agreement on Exchange of Information on Tax Matters, Paris, OECD Publishing.

OECD (2017) Model Tax Convention on Income and on Capital, Condensed Version 2017, Paris, OECD Publishing.

OECD (2019a) OECD Tax Database, Paris, OECD.

OECD (2019b) 'Government at a Glance - 2017 Edition: Public Finance and Economics', OECD Statistics, accessed at https://stats.oecd.org/\# on August 15, 2019.

Omartian, J. D. (2017) 'Do Banks Aid and Abet Asset Concealment: Evidence from the Panama Papers’, Available at SSRN 2836635.

Palan, R., Murphy, R. and Chavagneux, C. (2010) Tax Havens: How Globalization Really Works, Ithaca, N.Y, Cornell University Press.

Plümper, T., Troeger, V. E. and Manow, P. (2005) 'Panel Data Analysis in Comparative Politics: Linking Method to Theory’, European Journal of Political Research, 44, 327-354.

Plümper, T., Troeger, V. E. and Winner, H. (2009) 'Why Is There No Race to the Bottom in Capital Taxation?’, International Studies Quarterly, 53, 761-786.

Rixen, T. (2008) The Political Economy of International Tax Governance, Basingstoke, Palgrave Macmillan.

Rixen, T. and Schwarz, P. (2012) 'How Effective Is the European Union's Savings Tax Directive? Evidence from Four EU Member States*', JCMS: Journal of Common Market Studies, 50, 151-168. 
Schmitt, C. (2016) 'Panel Data Analysis and Partisan Variables: How Periodization Does Influence Partisan Effects’, Journal of European Public Policy, 23, 1442-1459.

Schmitt, C. and Zohlnhöfer, R. (2018) 'Partisan Differences and the Interventionist State in Advanced Democracies’, Socio-Economic Review.

Seabrooke, L. and Wigan, D. (2017) 'The Governance of Global Wealth Chains', Review of International Political Economy, 24, 1-29.

Sharman, J. (2008) 'Regional Deals and the Global Imperative: The External Dimension of the European Union Savings Tax Directive', JCMS: Journal of Common Market Studies, 46, 1049-1069.

Swank, D. and Steinmo, S. (2002) 'The New Political Economy of Taxation in Advanced Capitalist Democracies’, American Journal of Political Science, 46, 642-655.

Valkama, M. (2013) 'The Nordic Mutual Assistance Convention on Mutual Administrative Assistance in Tax Matters'. In Günther, O.-C. and Tüchler, N. (eds) Exchange of Information for Tax Purposes, Vienna, Linde Verlag, pp. 197-220. 


\section{Online Appendix}

New Room to Maneuver? National Tax Policy under Increasing Financial Transparency

\section{The Network Analysis Underpinning the INTS Score}

\section{Definition of Ties}

The Investment Network Transparency Score (INTS) relies on a network analysis on the portfolio investment data for OECD countries. We first need to define the ties that reflect relevant relationships between states for our purposes. To this end, we standardize the total portfolio investment indicator from the IMF's CPIS. The standardized indicator (SI) describes the portfolio investment from country A to country B as percentage share of the entire portfolio investment of country A. Most networks are binary since there is either a relationship between two nodes or not. But weighting relationships inside a network is also possible (Borgatti et al., 2013, pp. 11-23). To obtain weights that reflects the actual importance of each investment destination for a given country, we first look at the distribution of the SI for all countries in the IMF data as well as solely for the OECD countries. Both samples contain many small values of below 1.0 percent. For the sample of all countries the $75^{\text {th }}$ percentile has a value of 0.257 , while the $75^{\text {th }}$ percentile for OECD members only has a value of 0.194 . Nevertheless, both distributions seem to approximately follow the power law. Therefore, the following questions arise: When does the volume of portfolio investments become large enough to suppose a relevant relationship between two countries? Which value of the SI has to be reached?

To answer this question, it is important to look at the maximum values of the SI. Table 1 presents the maximum values for all OECD member states. The table shows that there is a substantial gap between the maximum value and the second highest value in most cases. The most important portfolio investment destination in a country's investment network accounts on average for 28.1 percent of all portfolio investment. In contrast, the runner up only reaches an 
average share of 12.7 percent. Moreover, if we look at the overall distribution of the SI separately for each country, we can see that there are only few high values (i.e. values over 5 percent). This means that in terms of portfolio investment, most countries only have a few important relationships to other countries. In the construction of the INTS we concentrate on these intensive ties. We assume that the financial secrecy level of a country has an impact on the tax policy of another country only if it accounts for a relevant share of its overall portfolio investment. Consequently, we assume a relationship between two states starting at an SI value of one percent. To reduce the complexity of the network, relationships not reaching this threshold are excluded. 
Table A1: Distribution of SI Values for OECD Member States

\begin{tabular}{|c|c|c|c|c|c|c|c|}
\hline Country & $\begin{array}{l}\text { Max. } \\
\text { Value }\end{array}$ & $\begin{array}{l}\text { Second } \\
\text { highest } \\
\text { value }\end{array}$ & $\begin{array}{l}\text { Third } \\
\text { highest } \\
\text { value }\end{array}$ & $\begin{array}{l}\text { Fourth } \\
\text { highest } \\
\text { value }\end{array}$ & $\begin{array}{l}\text { Fifth } \\
\text { highest } \\
\text { value }\end{array}$ & Median & Mean \\
\hline Australia & 42.3 & 9.2 & 5.3 & 4.1 & 3.1 & 0.062 & 1.06 \\
\hline Austria & 18.7 & 11.2 & 9.1 & 8.4 & 6.8 & 0.03 & 0.74 \\
\hline Belgium & 25.6 & 18.2 & 10.4 & 6.9 & 6.2 & 0.003 & 0.71 \\
\hline Canada & 59.4 & 7 & 4.5 & 2.9 & 2.6 & 0.015 & 0.88 \\
\hline Chile & 42.5 & 29.4 & 3.9 & 3.3 & 2.7 & 0.004 & 0.84 \\
\hline $\begin{array}{l}\text { Czech } \\
\text { Republic }\end{array}$ & 14.7 & 13.7 & 11.6 & 8.9 & 8.2 & 0.024 & 0.98 \\
\hline Denmark & 26 & 14.9 & 7.8 & 6.6 & 4.9 & 0.025 & 0.67 \\
\hline Estonia & 18.9 & 9.5 & 8.7 & 7.4 & 6.8 & 0.022 & 0.89 \\
\hline Finland & 11.6 & 11 & 10.8 & 9.2 & 9.1 & 0.016 & 0.86 \\
\hline France & 11.4 & 11 & 10.1 & 9.3 & 9 & 0.003 & 0.58 \\
\hline Germany & 17.3 & 12.8 & 9.7 & 8.8 & 7.3 & 0.01 & 0.68 \\
\hline Greece & 45.6 & 20.4 & 6.4 & 3.8 & 2.2 & 0.016 & 1.31 \\
\hline Hungary & 36.7 & 14.5 & 8.8 & 6.8 & 4.1 & 0.035 & 1.04 \\
\hline Iceland & 28.3 & 17.9 & 6.4 & 5.8 & 5.3 & 0.028 & 1.56 \\
\hline Israel & 59.7 & 7.5 & 5.6 & 3.1 & 2.2 & 0.006 & 0.6 \\
\hline Italy & 34.7 & 12.6 & 8.5 & 7.3 & 7.1 & 0.007 & 1.09 \\
\hline Japan & 36.6 & 16.6 & 6.2 & 5.5 & 4.5 & 0.005 & 0.65 \\
\hline $\begin{array}{l}\text { Korea, } \\
\text { Republic of }\end{array}$ & 40.5 & 6.8 & 5 & 4.8 & 4.7 & 0.004 & 0.69 \\
\hline Latvia & 18.6 & 12.4 & 8.6 & 7.5 & 6.2 & 0.008 & 0.7 \\
\hline Luxembourg & 22 & 9.5 & 9.4 & 7.8 & 5.2 & 0.053 & 0.85 \\
\hline Mexico & 82.9 & 2.8 & 1.6 & 1 & 0.4 & 0.008 & 0.51 \\
\hline Netherlands & 23.6 & 14.3 & 11 & 7.2 & 5.5 & 0.016 & 1.88 \\
\hline New Zealand & 15.7 & 10.1 & 2.4 & 2.1 & 1.2 & 0.01 & 0.66 \\
\hline Norway & 27.6 & 10 & 7.4 & 6.2 & 5.8 & 0.102 & 1.24 \\
\hline Poland & 31.9 & 12.6 & 4.8 & 4.8 & 4.5 & 0.009 & 0.7 \\
\hline Portugal & 14.1 & 12.1 & 11.5 & 10.5 & 8.6 & 0.061 & 1.29 \\
\hline $\begin{array}{l}\text { Slovak } \\
\text { Republic }\end{array}$ & 10 & 8.3 & 7.6 & 6.9 & 6.6 & 0.036 & 1.23 \\
\hline Slovenia & 15.2 & 12.7 & 8.9 & 8 & 7.1 & 0.079 & 1.2 \\
\hline Spain & 15.9 & 15.3 & 10.4 & 7 & 6.4 & 0.042 & 0.99 \\
\hline Sweden & 25.7 & 16.5 & 8.9 & 6.5 & 5 & 0.148 & 1.65 \\
\hline Switzerland & 18.6 & 14.8 & 7.4 & 7.3 & 6.4 & 0.004 & 0.66 \\
\hline Turkey & 22.2 & 17.6 & 15 & 13 & 5.7 & 0.002 & 0.51 \\
\hline $\begin{array}{l}\text { United } \\
\text { Kingdom }\end{array}$ & 25.9 & 7.1 & 7 & 5.9 & 5.7 & 0.045 & 1.1 \\
\hline United States & 13.7 & 11.4 & 9 & 7.6 & 4.9 & 0.006 & 0.5 \\
\hline
\end{tabular}




\section{Constructing the Network}

We use the SI to construct a directed and valued network for each year between 2001 and 2018. Figure A1 shows the network for 2001 as an example. However, the global network is too large to identify the investment networks of individual countries. For this reason, we use the OECD countries’ ego-networks, which include all nodes with a relationship to the respective country. For these networks, we construct core-periphery models to identify the crucial nodes in each year under study (Borgatti et al., 2013, p. 249). Figure A2 displays Austria’s ego-network in 2001 as an illustrative example for our general approach. The ego-network has 27 nodes, which corresponds to 11.1 percent of all nodes in the global network. The graph reveals a clear coreperiphery structure in the ego-network. Countries in the core are differentiated from countries in the periphery based on three criteria: (1) their share in all portfolio investment from Austria, (2) Austria's share in their overall portfolio investment, and (3) their relationships to third countries, which also have intense reciprocal investment relationships with Austria. By focussing on the countries in the core, we thus identify countries that play an important role in Austria's global wealth chains. Importantly, this not only includes direct links between Austria and other countries, but also the linkages to third countries. Since a tax evader is likely to invest through a legal entity registered in a (potentially secretive) third country, Austria and the countries popular among Austrian investors should figure among the more important destinations for portfolio investment from this secretive third country.

Figure A2 displays the core-fraction in blue and the periphery-fraction in grey. The following states are part of the core-fraction:

Austria

Canada

\section{Cayman Islands}

France 
Germany

Italy

Japan

Luxembourg

Netherlands

United Kingdom

United States

To obtain the INTS, we now check what information exchange arrangements Austria had agreed on with these countries in 2001 and allocate scores based on the coding scheme described in the main text. 


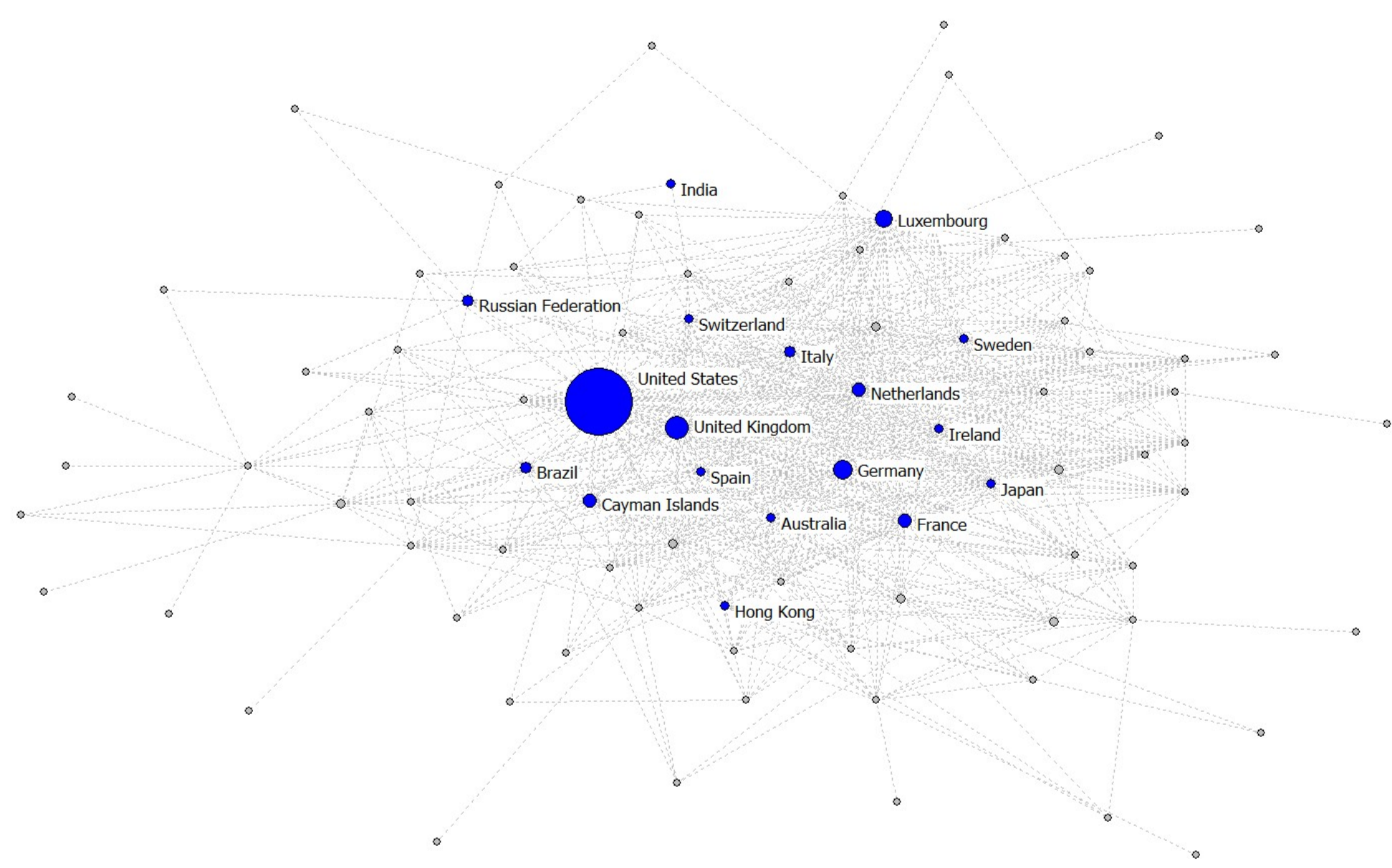

Figure A1: 2001 network without isolates 


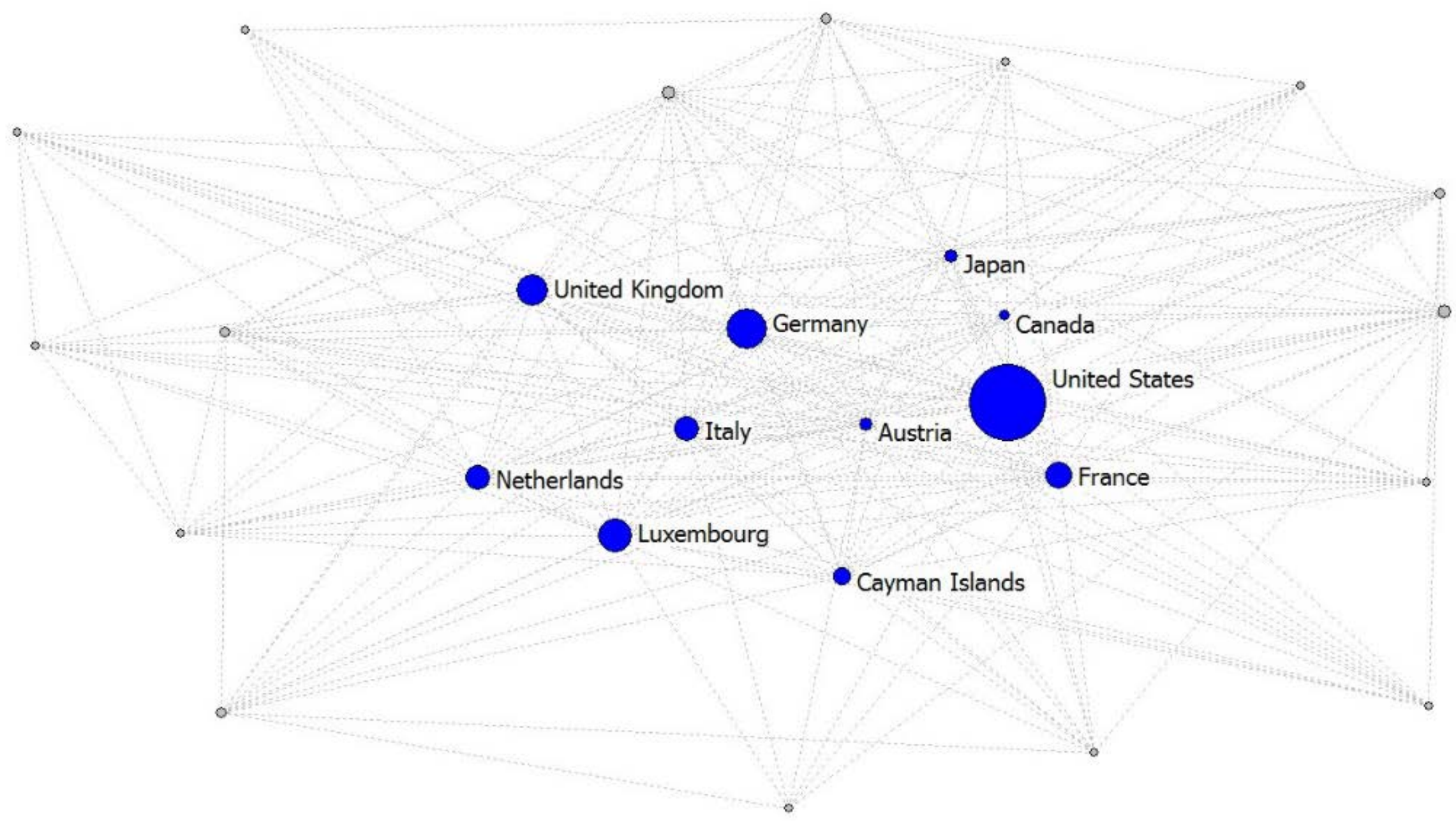

Figure A2: 2001 Ego-Network of Austria 

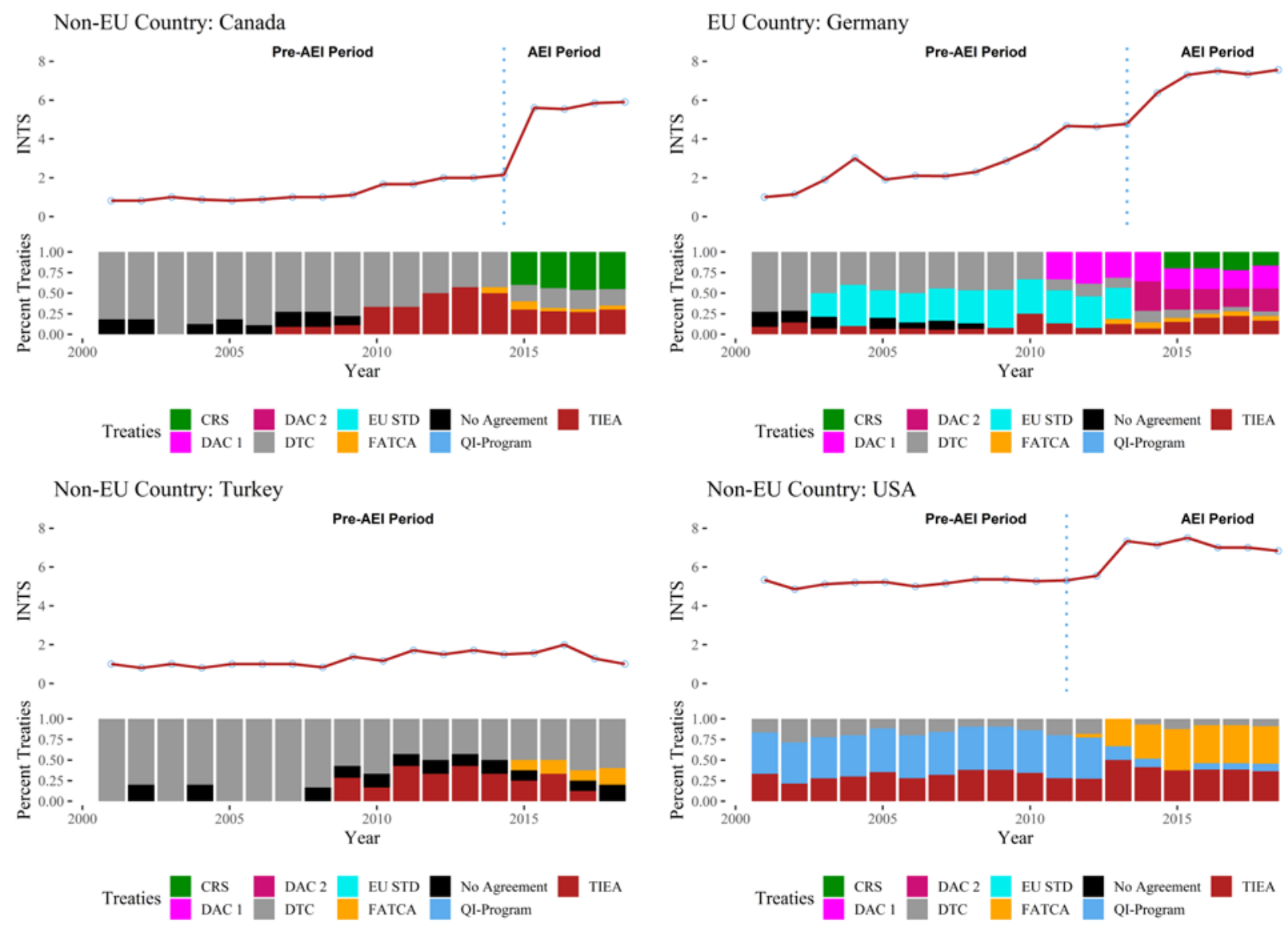

Figure A3: Country Examples replacement of treaties over time 


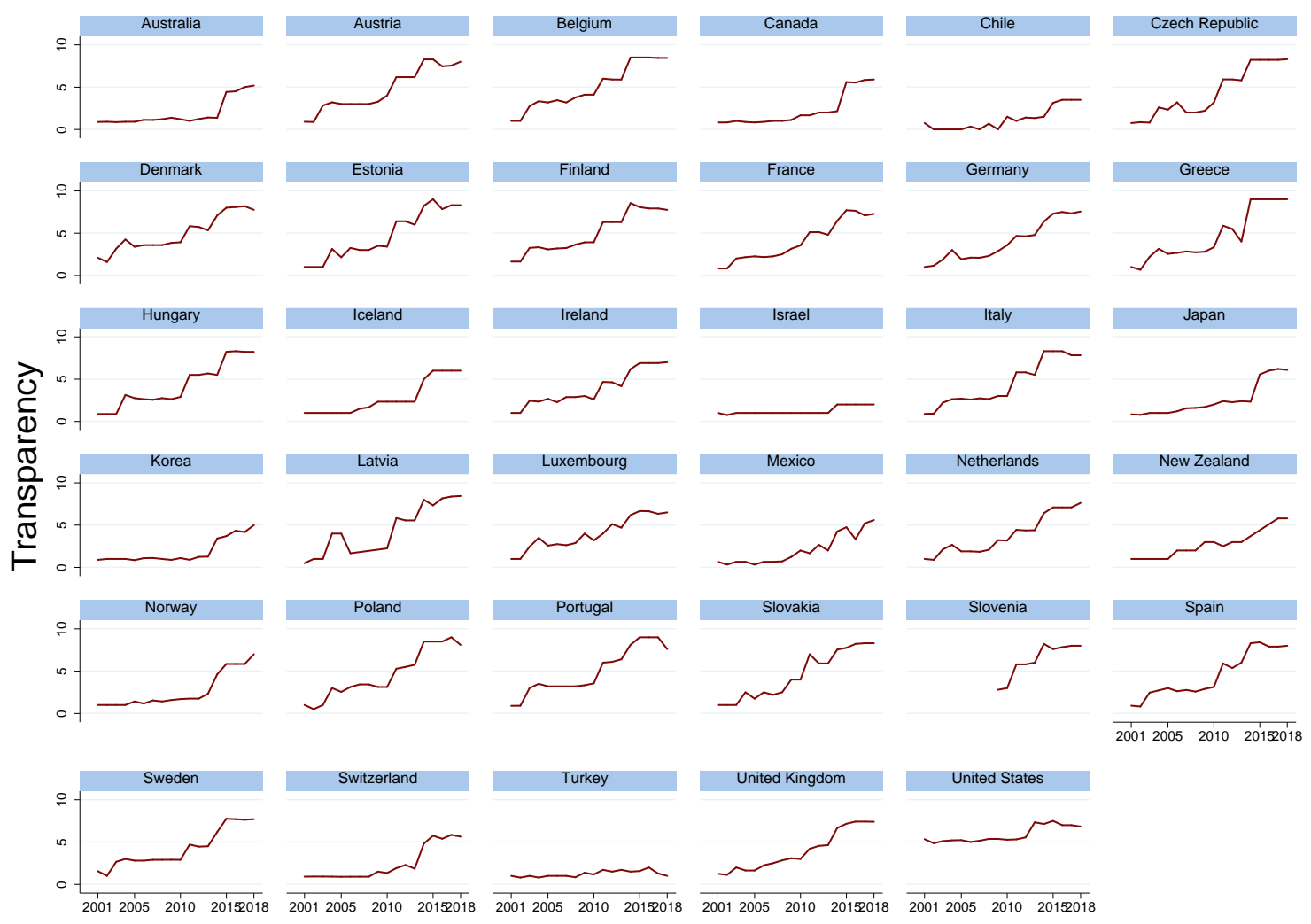

Figure A4: Country time series of the INTS

\section{Table A2: Descriptive statistics}

\begin{tabular}{lcccc}
\hline & Mean & SD & Min. & Max. \\
\hline Dividend tax rate & 0.34 & 5.59 & -33.6 & 28 \\
Left party dominance & 28.4 & 35.9 & 0 & 100 \\
Budget balance & -2.13 & 4.14 & -22.9 & 17.2 \\
Financial crisis & 0.21 & 0.41 & 0 & 1 \\
Capital/labor tax ratio & -0.47 & 0.27 & -1 & 0.15 \\
$\Delta$ Corporate tax rate & -1.02 & 2.51 & -12 & 6 \\
$\Delta$ Top marginal income tax rate & 0.0014 & 5.55 & -37.9 & 35 \\
Tax level & 33.5 & 7.32 & 12.1 & 51.6 \\
Tax structure & 33.9 & 11.6 & 17.3 & 65.4 \\
GDP per capita $(\log )$ & 10.3 & 0.41 & 9.26 & 11.2 \\
Cabinet duration $(\log )$ & 6.79 & 0.48 & 5.91 & 8.34 \\
\hline
\end{tabular}

$N=204$. 


\section{Robustness Checks}

\section{Model Description}

Model 1: Uses a categorical variable instead of the INTS index: Cabinet ended (1) before 2009, (2) between 2009-2013, and (3) between 2014-2018.

Model 2: Transparency is measured in terms of cabinet-specific changes instead of cabinet-specific averages.

Model 3: Inclusion of country fixed effects.

Model 4: Inclusion of period fixed effects.

Model 5: Uses robust standard errors clustered by countries.

Model 6: All variables that are measured in terms of first-half-of-cabinet levels instead use the first-year value.

Model 7: The variables corporate and income tax rate (both measured as cabinet-specific changes) are dropped. 
Table A3: Alternative specifications

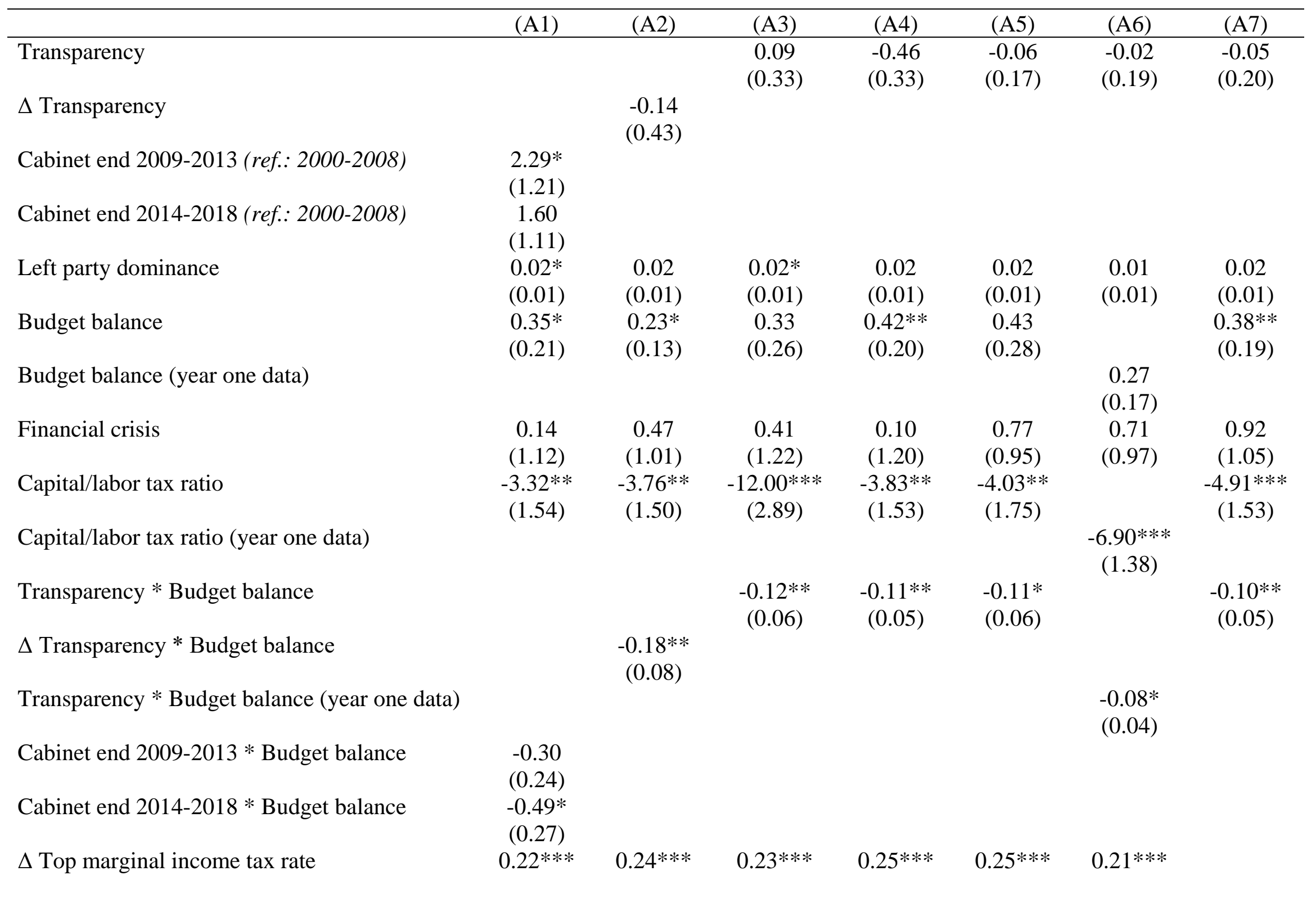




\begin{tabular}{|c|c|c|c|c|c|c|c|}
\hline & $(0.07)$ & $(0.07)$ & $(0.08)$ & $(0.07)$ & $(0.07)$ & $(0.07)$ & \\
\hline$\Delta$ Corporate tax rate & $\begin{array}{c}-0.36^{* *} \\
(0.17)\end{array}$ & $\begin{array}{l}-0.18 \\
(0.17)\end{array}$ & $\begin{array}{l}-0.26 \\
(0.19)\end{array}$ & $\begin{array}{c}-0.33^{*} \\
(0.18)\end{array}$ & $\begin{array}{l}-0.29 \\
(0.18)\end{array}$ & $\begin{array}{l}-0.26 \\
(0.17)\end{array}$ & \\
\hline GDP per capita (log) & $\begin{array}{c}0.58 \\
(1.38)\end{array}$ & $\begin{array}{c}1.70 \\
(1.32)\end{array}$ & $\begin{array}{c}5.77 \\
(4.20)\end{array}$ & $\begin{array}{c}0.62 \\
(1.42)\end{array}$ & $\begin{array}{c}1.37 \\
(1.10)\end{array}$ & & $\begin{array}{c}1.99 \\
(1.37)\end{array}$ \\
\hline GDP per capita (log) (year one data) & & & & & & $\begin{array}{l}2.51^{*} \\
(1.28)\end{array}$ & \\
\hline Tax level & $\begin{array}{c}0.04 \\
(0.06)\end{array}$ & $\begin{array}{c}0.01 \\
(0.06)\end{array}$ & $\begin{array}{c}-0.05 \\
(0.27)\end{array}$ & $\begin{array}{c}0.07 \\
(0.07)\end{array}$ & $\begin{array}{c}0.02 \\
(0.07)\end{array}$ & & $\begin{array}{c}0.01 \\
(0.06)\end{array}$ \\
\hline Tax level (year one data) & & & & & & $\begin{array}{c}-0.01 \\
(0.06)\end{array}$ & \\
\hline Tax structure & $\begin{array}{c}0.01 \\
(0.04)\end{array}$ & $\begin{array}{c}-0.00 \\
(0.04)\end{array}$ & $\begin{array}{c}-0.02 \\
(0.20)\end{array}$ & $\begin{array}{c}0.00 \\
(0.04)\end{array}$ & $\begin{array}{c}0.00 \\
(0.03)\end{array}$ & & $\begin{array}{c}0.00 \\
(0.04)\end{array}$ \\
\hline Tax structure (year one data) & & & & & & $\begin{array}{c}-0.01 \\
(0.04)\end{array}$ & \\
\hline Cabinet duration (log) & $\begin{array}{l}-1.61^{*} \\
(0.88)\end{array}$ & $\begin{array}{l}-1.47 \\
(0.92)\end{array}$ & $\begin{array}{c}-0.28 \\
(1.02)\end{array}$ & $\begin{array}{c}-1.67 * \\
(0.90)\end{array}$ & $\begin{array}{c}-1.62 * \\
(0.89)\end{array}$ & $\begin{array}{c}-1.54^{*} \\
(0.83)\end{array}$ & $\begin{array}{c}-1.81^{* *} \\
(0.87)\end{array}$ \\
\hline Constant & $\begin{array}{c}-0.02 \\
(13.64)\end{array}$ & $\begin{array}{l}-10.00 \\
(13.38)\end{array}$ & $\begin{array}{l}-62.72 \\
(45.44)\end{array}$ & $\begin{array}{c}-0.80 \\
(13.98)\end{array}$ & $\begin{array}{c}-6.29 \\
(11.74)\end{array}$ & $\begin{array}{l}-18.82 \\
(12.98)\end{array}$ & $\begin{array}{c}-11.38 \\
(13.77)\end{array}$ \\
\hline Observations & 204 & 204 & 204 & 204 & 204 & 204 & 204 \\
\hline $\mathrm{R}^{2}$ & 0.18 & 0.16 & 0.23 & 0.19 & 0.16 & 0.23 & 0.10 \\
\hline Country FE & No & No & Yes & No & No & No & No \\
\hline Year FE & No & No & No & Yes & No & No & No \\
\hline Country-clustered standard errors & No & No & No & No & Yes & No & No \\
\hline
\end{tabular}

Note: ${ }^{* * *} p<.01,{ }^{* *} p<.05,{ }^{*} p<.1$. Robust standard errors clustered around countries in parentheses. 